\title{
Relevance of Health Economics in Breast Cancer Treatment - the View of Certified Breast Centres and Their Patients
}

\author{
Michael Lux ${ }^{\mathrm{a}}$ Thomas Hildebrandt ${ }^{\mathrm{a}}$ Elke Beyer-Finkler ${ }^{\mathrm{b}} \quad$ Mayada Bani $^{\mathrm{a}}$ Christian Loehberg $^{\mathrm{a}}$ \\ Sebastian Jud ${ }^{\mathrm{a}}$ Claudia Rauh $^{\mathrm{a}} \quad$ Michael Schrauder $^{\mathrm{a}}$ Peter Fasching ${ }^{\mathrm{a}}$ Matthias Beckmann ${ }^{\mathrm{a}}$
}

aUniversity Breast Centre for Franconia, Department of Gynaecology, Erlangen University Hospital,

${ }^{b}$ Frauenselbsthilfe nach Krebs e.V., Erlangen, Germany

\section{Keywords}

Breast cancer - Certified centres - Economics .

Health economics · Cost-effectiveness

\section{Summary}

Breast cancer centres - certified in accordance with the criteria of the German Cancer Association and the German Mastology Association - are established throughout Germany. Although the setting up of centres and the subsequent need for certification are associated with a marked increase in costs, initial data show positive effects on quality. Certified centres are cost-effective from the point of view of health economics - they lead to improved quality in processes and results without creating any increase in costs for the funding bodies. However, the organization of the necessary structures, with interdisciplinary treatment, documentation and qualityassurance measures, requires considerable resources. Increasing consolidation of inpatient services is also involved, while shortening of the patients' hospitalization periods is leading to reduced remuneration from the funding bodies. The current cost deficits, which have resulted from the increased resources required, need to be recouped through additional charges. It will only be possible to maintain the high quality achieved if additional charges become available to cover the centres' added costs. Good data are increasingly becoming available as a basis for negotiations on charges - e.g., with regard to the quality of results and the National Cancer Plan - as well as clear support from patients.

\section{Schlüsselwörter}

Mammakarzinom - Zertifizierte Brustkrebszentren • Ökonomie · Gesundheitsökonomie · Kosteneffektivität

\section{Zusammenfassung}

Es ist unbestritten, dass wir im Zeitalter der zertifizierten Zentren leben. Im Bereich der Senologie sind insbesondere die zertifizierten Brustkrebszentren nach den Kriterien der Deutschen Krebsgesellschaft e.V. und der Deutschen Gesellschaft für Senologie e.V. flächendeckend etabliert. Auch wenn die Zentrumsbildung mit nachfolgender Zertifizierung mit deutlichen Mehrkosten verbunden ist, zeigen erste Daten auf, dass sich diese positiv auf die Ergebnisqualität auswirken. In Bezug auf die Gesundheitsökonomie sind zertifizierte Zentren aus der Sicht des Gesundheitswesens kosteneffektiv - es wird eine Verbesserung der Prozess- und Ergebnisqualität erreicht, ohne dass die Kostenträger Mehrkosten haben. Demgegenüber besteht ein enormer Ressourcenaufwand für Organisation der Strukturen, interdisziplinäre Betreuung, psychoonkologische Versorgung, sozialmedizinische Beratung, Dokumentation und Qualitätssicherung. Des Weiteren erfolgt eine zunehmende Konzentration der stationären Leistungen. Dem gegenüber werden durch Kürzungen der Verweildauer der Patientinnen durch die Kostenträger Abzüge der Honorierung erzwungen. Die aktuell fehlende Kostendeckung der zertifizierten Brustkrebszentren muss durch spezifische Zuschläge ausgeglichen werden. Diese fehlen allerdings größtenteils. Auf lange Sicht wird die hohe Qualität jedoch nur aufrechterhalten werden können, wenn Zuschläge den Mehraufwand der Zentren abdecken. Für die Verhandlungen dieser Zuschläge besteht mittlerweile eine zunehmend gute Datenlage, z.B. in Hinblick auf die Ergebnisqualität und den Nationalen Krebsplan, als auch eine deutliche Unterstützung durch die Patientinnen.

\section{KARGER \\ Fax +497614520714 \\ Information@Karger.com}

www.karger.com (c) 2013 S. Karger GmbH, Freibur

$1661-3791 / 13 / 0081-0015 \$ 38.00 / 0$

Accessible online at:

www.karger.com/brc
PD Dr. med. Michael P. Lux

Universitäts-Brustzentrum Franken

Frauenklinik

Universitätsklinikum Erlangen

Universitätsstrasse 21-23, 91054 Erlangen, Germany

fk-direktion@uk-erlangen.de 


\section{From the Point of View of the Certified Breast Cancer Centres}

\section{Background to Certified Breast Cancer Centres}

The healthcare system in Germany is currently undergoing a wave in which centres subject to certification procedures are being established. The setting up of centres involves the spatial and structural fusion of collaborating disciplines and departments. Due to the shortage of resources in the German healthcare system and recent legislation in a changing hospital market, hospitals are being forced to reduce overcapacity, while they have the option of increasing cost-effectiveness and simultaneously optimizing the quality of care through a forward-looking approach involving the formation of centres [1]. Establishing and certifying centres is regarded in principle as a way of ensuring and optimizing the quality of diagnosis and treatment. Combining the skills of interdisciplinary specialists has numerous advantages, but it also requires a number of changes [2]. These particularly affect the certified breast cancer centres that now universally care for patients with breast carcinoma throughout Germany. Not least due to the large numbers of patients - breast cancer is the most frequent type of cancer in women, with 71,660 new cases per year $[3,4]$ - the care provided in certified breast cancer centres is of particular importance in relation to health economics.

The most widespread specialist certification system is that provided by the German Cancer Association (Deutsche Krebsgesellschaft, DKG) and the German Mastology Association (Deutsche Gesellschaft für Senologie, DGS). As a multidisciplinary specialist society, the DKG envisages a 3 -stage model for the future care of patients in the field of oncology [5]. The third and highest level in the oncological care structure and type of centre formed consists of leading oncological centres known as Comprehensive Care Centres (CCCs) [6]. The second stage consists of oncological centres that treat several types of tumour entity and comprise several organ cancer centres [7]. In addition to a catalogue of organspecific requirements, these oncological centres also have to provide additional resources that are organized and pooled for multiple organs. The basic level in the DKG's 3-stage model is represented by the organ cancer centres, such as breast cancer centres [7]. The prerequisites for certification include efficient organizational and decision-making approaches capable of achieving a high level of quality in accordance with the guidelines. Additional specialist requirements list the content and requirements for interdisciplinary collaboration in a centre, the numbers and level of expertise of its employees, the technical equipment required, and processes and treatment pathways. In addition, psychosocial care, including rehabilitation and psycho-oncology, represents an important area of treatment. A total of 690 organ cancer centres are currently certified by the DKG in Germany, including 205 breast cancer centres with 262 certified locations.
At the international level, accreditation by the European Society of Mastology (EUSOMA) is possible [8]. In addition to case numbers, high standards of care provision are required for this in all areas, including human genetics, prevention and palliation, patient support and social services. The advantages of these certified breast centres include improved quality of care resulting from interdisciplinary collaboration, as well as optimized structures and processes. However, all of the certification procedures involved are associated with greater resource usage so that the economic aspects also have to be taken into consideration.

\section{Economic Problems of Caring for Breast Carcinoma Patients in Certified Structures}

It has been shown previously in several publications that care for patients with breast carcinoma in certified breast cancer centres is not at present adequately remunerated and that additional charges are needed in order to cover costs in certified structures [9-12]. One of the major problems is that certain costs do not qualify for remuneration. These include work involved in (re-)certification processes and costs for meeting obligatory quality criteria such as further education and training [13], research involving molecular and clinical studies, multiple documentation (e.g., for the Institut für angewandte Qualitätsförderung und Forschung im Gesundheitswesen, AQUA and for maintaining a clinical and epidemiological cancer registry), coordination of the centre, additional support for affected patients and their families, and provision of infrastructure for interdisciplinary partners. The individual costs of a certified breast cancer centre have been examined in other analyses [10,14]. It was found that setting up a quality management system alone, with the costs of certification and annual audits, involves costs of $€ 237,303$ over 4 years. These uncovered costs stand in strong contrast to demands from the field of healthcare politics for constant optimization of the quality of treatment and results.

\section{Specific Economic Problems in Certified Structures}

\section{Documentation}

Establishing oncological centres with certification from independent external assessors and specialist societies has both quality assurance effects and quality optimizing effects. However, providing the relevant data means that the parameters for the various quality dimensions have to be measurable. An important aspect that requires substantial resources is the need for both individual and multiple documentation. Numerous additional parameters have to be documented in every unit in the chain of care for a patient in order to meet the requirements for quality assurance and optimization, and also to meet the legal and specialist requirements for certified
16

Breast Care 2013;8:15-21
Lux/Hildebrandt/Beyer-Finkler/ Bani/Loehberg/Jud/Rauh/Schrauder/ Fasching/Beckmann 
structures. Clinical cancer registries provide important assistance here, particularly in recording the quality of results. However, the registries vary widely at present in terms of their follow-up rate and also in the support they provide for certified centres which consequently often have to record follow-up data using their own measures (e.g., by writing to and phoning physicians in private practice, etc.). High costs are thus continuing to arise at present.

\section{Consolidation of Inpatient Services and Reduced Revenue due to Shortening of Hospital Stays}

Another problem in patient care is the increasing consolidation of services during ever-shorter hospital stays, with services being shifted to the outpatient area, as the statistics published by the German Hospital Association (Deutsche Krankenhausgesellschaft) show. For example, the numbers of hospitals and hospital beds in Germany have been declining for years. The shortening of hospital stays despite an increase in cases and hospitalization frequency is explained by a progressive qualitative improvement in hospital conditions, cost-reduction measures and the flat rate remuneration system [15] - the latter not always being to the advantage of the hospitals or certified centres. In addition, mention should be made of the efforts being undertaken by funding bodies, with the assistance of the Health Insurance Companies' Medical Service (Medizinischer Dienst der Krankenkassen, MDK), to verify hospital stays and cancel numerous inpatient days claimed or shift inpatient services into the outpatient field. Cost remuneration for surgical procedures is regulated in Germany in accordance with the diagnosis-related groups (G-DRG) system which is a flat case rate system. The case rates set the mean inpatient hospitalization period for patients for a regular treatment [16]. For breast-conserving treatment with a sentinel node biopsy, this amounts to 5.7 days, for example. To protect patients from being prematurely discharged, the hospital loses one-third of the case rate if the patient is discharged earlier. During verification procedures, hospital days are increasingly not being recognized so that the patients fall below the threshold hospitalization period. This results in cuts in remuneration. In the view of the funding bodies, aspects such as psycho-oncological care, radioactive marking during sentinel node biopsy, discussions with the patient and relatives, sociomedical consultations and other care services do not justify hospitalization. Due to an absence of universally available networks, however, this overall oncological approach cannot be ensured during hospitalization periods of only a few days or in the outpatient sector.

\section{Failure to Reflect Complex Surgical Procedures}

The failure of the G-DRG system to reflect complex breast procedures, which leads to a lack of remuneration for the resources required, is another burden for the centres. A DRG is calculated in each case from the International Statistical Classification of Diseases and Related Health Problems (ICD) code and from the Official Classification for Operation and Treatment Procedures (OPS) code [17]. In 2011, the OPS code for procedures in the breast and axilla was revised in order to reflect the work involved in complex breast operations in a more nuanced way. For example, tumour-adapted mastopexy or reduction mammoplasty during breast-conserving therapy can be coded in detail. The problem is that the procedures usually lead to the same DRG and thus to identical remuneration, no matter how complex they are [17]. Similar problems apply to ablative breast procedures as well. For example, radical mastectomy and modified radical mastectomy lead to the same DRG, with or without axillary dissection. The costs of surgical procedures with prosthetic reconstruction are also not usually reflected in such a way as to cover costs [18]. As a consequence, certified breast cancer centres in particular, having large numbers of cases involving more complex procedures, are unable to cover their costs.

\section{Psycho-Oncological Care}

Studies have reported that $25-30 \%$ of all patients require psycho-oncological care during the course of a malignant disease $[19,20]$. Oncology patients often suffer from psychological and psychosomatic symptoms, resignation and dejection, or a fear of progression [21, 22]. Access to psycho-oncological counselling and treatment must be ensured in certified organ cancer centres, and the process has to be evidentially validated [23]. In addition, to care for patients and their relatives, this area of activity includes supervision and further training for the staff involved, internal quality assurance and documentation, and possibly research as well. An adequate rate of psycho-oncological care is prescribed in the requirements for certified breast centres. The rate is calculated by the number of primary patients who have received care as a proportion of the centre's total case numbers. According to the annual report of the certified breast cancer centres for 2012 [24], a median of $65.6 \%$ of all patients receive psycho-oncological care. Several aspects need to be taken into account here. Although psycho-oncological and psychotherapeutic services can now be coded in a more nuanced way using OPS numbers, they do not have any effect on remuneration [25]. In addition, only a short period for additional inpatient measures is left postoperatively in the context of the cuts in hospitalization periods mentioned above. Alongside postoperative convalescence, further sociomedical counselling and intensive discussions have to be carried out so that psycho-oncological care falls into the outpatient field. As the patients' anxieties usually only develop several days after the operation when they become fully aware of the implications of the diagnosis of cancer, further outpatient psycho-oncological care is invaluable. At present, oncology patients only have limited access to psychotherapeutic assistance in the outpatient sector [23]. The certified centres thus usually carry out the outpatient care in this area during the subsequent course as well. Very few certified breast cancer centres have their own authorization 
for this so that these services are usually carried out without the costs being covered from the centre's resources.

\section{Self-Help Groups}

Another important element in the certified breast cancer centres is the way in which they cooperate with self-help groups; such collaboration is promoted in accordance with DKG and DGS requirements. Access to self-help groups must be available in every phase of treatment. In addition, regular provision of facilities in the breast cancer centre for discussions with patients, personal conversations between the selfhelp groups and the breast cancer centre, and contributions by the centre to events organized by the self-help group all take place. Clearly, both material resources (costs for room use) and personnel resources (including active contributions by doctors - e.g., in presenting talks) are required for this, which are not reflected in any form of remuneration structure. It should also be emphasized that the work done by the selfhelp groups' members is carried out on a voluntary basis, again without remuneration.

\section{Legal Basis and Options for Financing Certified Structures}

There is a legal basis for the financing of the additional costs involved in certified centre structures (German Hospital Remuneration Law - Section 5, Paragraph 2) [11, 26]. This specifies that a claim to an additional charge arises if a centre or a focus of expertise is present. Arbitration bodies have already established that a certified breast cancer centre represents a centre qualifying to levy additional charges under Section 2 of the Hospital Remuneration Law, so that an additional charge in accordance with Section 5, Paragraph 3 of the law is justified. However, the services provided have to be explicitly specified. The cost accounting must also show that these are not general services arising in any hospital but represent special services that have to be financed through additional charges (table 1). The criteria mentioned are usually met by a certified breast cancer centre, including the interdis- ciplinary tumour conference, management of research studies, psycho-oncological care, documentation and introduction of quality management. However, additional charges for certified centres in Germany are still granted in very different ways depending on the region or federal state concerned. This was already confirmed in 2010 through questionnaire studies conducted by the Certified Breast Cancer Centres Working Group [11]. Only 20 of 110 breast cancer centres (18.2\%) stated that they were receiving charges additional to the DRG remuneration. The debate over additional charges for centres has intensified since 2010, and the question therefore arises of whether any improvements have since taken place. In March 2012, a further questionnaire survey on the topic of financing through additional charges in certified breast cancer and bowel cancer centres was carried out [27]. A total of 267 centre directors took part of 427 centres contacted (204 breast cancer centres and 223 bowel cancer centres), giving a response rate of $63 \%$. Among these, 24 breast cancer centres and 10 bowel cancer centres stated that they were receiving additional charges for the certified centre. The various sources of the additional charges were of interest here. In $15 \%$ of cases, the additional charges were obtained due to agreements following arbitration procedures, and in $26 \%$ they were based on supplementary contracts with the health insurance companies. While $24 \%$ of the centres were receiving remuneration for additional charges directly from the funding body and $9 \%$ from charitable or foundation funds, only $26 \%$ of the additional charges were received on the basis of Section 5, Paragraph 3 of the Hospital Remuneration Law. All of the centres ( $n=267)$ were also asked whether they had already applied for support in accordance with Section 5 of the Hospital Remuneration Law. $61 \%$ of the centres said they had not, while $36 \%(\mathrm{n}=96)$ stated that they had submitted an application although with a negative outcome in $62.5 \%$ of cases. These figures make it clear that additional charges are rarely paid ( $13 \%$ of the centres), and that the distribution of such remuneration is extremely heterogeneous in Germany. If additional charges are paid, only one-quarter of the payments are based on the legal framework.

Table 1. Criteria applying to a legitimate claim for additional charges

\begin{tabular}{|c|c|}
\hline Special services for the centre's own patients & $\begin{array}{l}\text { psycho-oncological support (including relatives) } \\
\text { special documentation } \\
\text { clinical registry } \\
\text { clinical trials }\end{array}$ \\
\hline Certification & in accordance with the German Cancer Association \\
\hline Special services provided beyond the hospital & $\begin{array}{l}\text { advanced training } \\
\text { for the centre's collaborators } \\
\text { for collaborating partners }\end{array}$ \\
\hline & $\begin{array}{l}\text { support for outpatients (e.g., discussion at the interdisciplinary tumour conference, } \\
\text { with special documentation) } \\
\text { quality assurance meetings }\end{array}$ \\
\hline
\end{tabular}


Specialization through the establishment and certification of centres is in principle recognized as a way of ensuring and improving the quality of diagnosis and treatment. Data from a 'key informant' questionnaire, in which higher-level employees provide information about the characteristics of an organization [28], are available on the topic. The directors or coordinators of certified breast cancer centres were surveyed in 2011 using a special questionnaire in order to investigate the extent to which certified structures are accepted. A total of 149 of 243 locations participated; $87.1 \%$ of the respondents regarded certification of breast cancer centres as improving the quality of interdisciplinary tumour conferences, $93.3 \%$ regarded it as improving the quality of psycho-oncological care, $59.2 \%$ considered that it improved contact with physicians in private practice, and $98.8 \%$ saw it as improving the quality of patient care. No deterioration was noted in response to any of the questions. In addition to assessment of optimized organizational structures provided by certified centres, their influence on the quality of results also needs to be examined. Very few studies are available on this in the literature, and the published reports have clear limitations such as a lack of control groups. The establishment or certification of centres has never been a direct studied parameter, only the individual criteria that define a centre $[26,29]$. To date, there has therefore been a lack of conclusive evidence that a certified centre achieves better-quality results or represents a prognostic parameter in relation to a carcinoma independent of other influencing factors. However, this has now been demonstrated with a high level of significance in relation to improvements in the mortality rate [30]. Data for 3,940 breast carcinoma patients from 3 certified centres and 18 other non-certified treatment units in Central Franconia were analysed. It was found that the overall survival after 4 years was $30 \%$ better in patients who were treated in a certified breast cancer centre - independent of tumour characteristics or other patient characteristics such as age. Similar results have also been presented based on a single-centre study at the Heidelberg University Hospital breast centre. A total of 3,338 patients treated at the certified Heidelberg breast centre from 2003 to 2010 also had a better survival rate in comparison with Germany as a whole [31]. With the data now available showing the improved quality of processes and results, it can be assumed that certified centres are cost-effective from the point of view of the healthcare system. Since legislators are looking at the cost-effectiveness of certified centres while ignoring costs that are not currently refundable, they inevitably regard these as outstanding results. The breast cancer centres are, of course, unable to share this view. For them, quality assurance methods and the provision of additional resources in most cases represent unremunerated investment.

\section{From the Patients' Point of View}

One of the largest patient surveys on cancer centres in Europe was recently published $[32,33]$. A total of 128 centres participated, from which 7,301 patients returned questionnaires. The results impressively showed that patients feel that they receive good-quality care in the certified breast cancer centres. On a scale of 1-5, aspects such as organization (4.56), medical treatment (4.76), success of the treatment (4.50), information flow (4.42), psychosocial care (4.05), psycho-oncological care (3.99), the involvement of physicians providing continued treatment (4.26) as well as the involvement of relatives (4.00) were given positive assessments. However, the additional services provided - such as psycho-oncological care and the complex integration of everyone involved - are associated with time and staffing resources in certified centres and thus represent an economic burden for them. Despite this good assessment, the question arises of whether patients attach importance to receiving care in a certified centre. A prerequisite for evaluating certified centres is an awareness of their function, as well as the availability of a centre. In a survey including 1,073 patients in a department of gynaecology in Germany conducted in $2007,65.6 \%$ of the patients were found to be familiar with certified centres [34]. In a further survey including 2,389 patients contacted between 2007 and 2008, the availability of a centre or the presence of certification, respectively, represented the major reason for recommending the hospital or for presenting there again in $34.3 \%$ and $43.5 \%$ of cases [35]. The data available show on the one hand that the perception and appreciation of care in certified structures have substantially increased in recent years, and on the other that a high level of penetration of the idea of establishing and certifying centres has already developed among the patients affected. Care in this type of structure is explicitly desired by the patients. It is therefore justifiable to involve the patients in an assessment of additional remuneration for certified structures through additional charges. Data from what is known as a willingness-to-pay analysis are available for gauging the patients' view of the economic aspects of certified centres [36]. The basis for this analysis was the problem that additional charges for certified centres are often not remunerated, on the one hand, while on the other hand the ability to calculate additional costs was limited because interdisciplinary services are not reflected in the data used by the Institute for the Hospital Remuneration System (Institut für das Entgeltsystem im Krankenhaus, InEK). In a multicentre study, 2,469 patients at 1 university hospital and 1 non-university hospital were asked about their awareness of certified centres, the influence of a centre's existence on their presentation at a hospital, and their personal attitudes towards quality-oriented remuneration. Their subjective assessment of possible additional charges was calculated using the willingness-to-pay analysis. In the overall group, $53.4 \%$ of the patients knew what a certified centre was and $27.4 \%$ had some 
information about it. The level of information was highest among mastology patients (mastology $66.8 / 23.2 \%$, versus obstetrics $40.0 / 32.3 \%$, versus gynaecology/oncology $54.7 / 27.3 \%$; $\mathrm{p}<0.001)$. The existence of the certified centre was the main reason or one reason for presenting there for nearly $70 \%$ of the mastology patients. Quality-oriented remuneration was approved by $72.6 \%$ of the respondents, and $69.7 \%$ approved of an additional charge for a certified centre at the level of $€ 538.56$. The average additional charge that the patients regarded as justified was highest in the mastology group at $€ 643.65$ (obstetrics $€ 474.67$, gynaecological oncology $€ 532.47$ ). A total of $33.9 \%$ of the respondents would be willing to pay an increase in their health insurance premiums in order to finance this $(0.3865 \%$ on average $)$. A reduction in the remuneration paid to non-certified centres was approved by $28.3 \%$. Additional charges for certified centres are also advocated by the patients themselves, as they recognize that numerous additional resources are used by the centres to provide optimal care.

\section{Conclusion and Prospects}

A universal network of certified breast cancer centres has been established in Germany in order to ensure interdisciplinary and quality-assured oncological care at the highest level for patients with breast carcinoma. The patients have a high level of awareness of the existence of certified centres and clearly support them. In addition, initial data on the quality of the results show that overall survival is optimized as a result of care in certified structures. From the point of view of the healthcare system, certified breast centres represent an absolutely cost-effective structure, since the centres' additional resource consumption is usually not additionally remunerated. Federal regulation of additional charges for certified organ cancer centres is required.

\section{Disclosure Statement}

The authors declare that they have no conflict of interest.

\section{References}

1 Neubauer G, Minartz C: Zentrierte Versorgung - Ziele und Optionen; in Klauber J, Robra BP, Schellschmidt H (eds): Krankenhaus-Report 2008/ 2009 (Schwerpunkt: Versorgungszentren). Stuttgart, Schattauer Verlag, 2009, pp. 3-16.

2 Quante S: Das Krankenhaus in neuen Versorgungskonstellationen - Kooperationen und Netzwerke; in Debatin JF, Schulte B (eds): Krankenhausmanagement: Strategien, Konzepte, Methoden. Berlin, MWV Medizinisch-Wissenschaftliche Verlagsgesellschaft, 2010, pp. 89-95.

3 Fasching PA, Ekici AB, Adamietz BR, Wachter DL, Hein A, Bayer CM, Häberle L, Loehberg CR, Jud SM, Rübner M, Rauh C, Bani MR, Lux MP, SchulzWendtland R, Hartmann A, Beckmann MW Breast cancer risk - genes, environment and clinics. Geburtshilfe Frauenheilkd 2011;71:1056-1066.

4 Robert Koch-Institut/Gesellschaft der epidemiologischen Krebsregister in Deutschland e. V.: Krebs in Deutschland 2007/2008. 8th ed. Berlin, Robert Koch Institut, 2012. www.rki.de/Krebs/DE/Content/ Publikationen/Krebs_in_Deutschland/kid_2012/ krebs_in_deutschland_2012.html.

5 Beckmann MW, Adler G, Albers P, Bruns J, Ehninger G, Hauschild A, Neuhaus P, Schmiegel W, Schmitz S, Schmoll HJ, Weller M, Wiegel T, Bamberg M: Onkologie Dreistufenmodell optimiert Behandlung unter Kostendeckung. Wie die künftigen Strukturen der onkologischen Versorgung in Deutschland aussehen sollten. Dtsch Ärztebl 2007;104:A-3004/B-2644/C-2562.

6 Bamberg M: Konzeption für neue Versorgungsstrukturen in der Onkologie. Forum DKG 2006;7:34-36

7 Wesselmann S, Follmann M: Leitlinien und Zertifizierung im DKG-Qualitätszirkel. Forum 2011;3:1517.

8 Blamey RW, Cataliotti L: The requirements of a specialist breast unit; in Perry N, Broeders M, de Wolf C, Törnberg S, Holland R, von Karsa L (eds): European Guidelines for Quality Assurance in Breast Screening and Diagnosis. 4th ed. Luxembourg, Office for Official Publications of the European Communities, 2006, pp. 343-354.

9 Köckemann M, Lillteicher F: Entgeltverhandlungen 2007 - folgt das Geld der Qualität? Die bislang ausgebliebene Finanzierung zusätzlicher Strukturqualität von Brustzentren in Nordrhein-Westfalen. Krankenhaus 2007;5:439-445.

10 Wagner S, Ganslandt T, Keiling CM, Jap D, Fasching PA, Lux MP, Beckmann MW: Ist ein Brustzentrum finanzierbar? - Ein Kalkulationsmodell für das Universitäts-Brustzentrum Franken (UBF). Geburtshilfe Frauenheilkd 2007;9:966-973.

11 Beckmann MW, Bader W, Bechtold I, Becker S, Bornhaupt J, Dimpfl T, Friese K, Frobenius W, Gembruch U, Grüssner S, Heer IM, Kayser D, Kreienberg R, Petri E, Rimbach S, Scharl A, Schmidt S, Schwenzer T, Solomayer E, Steiner E, Vetter K, Wallwiener D, Lux MP: Finanzierung und finanzielle Probleme von Leistungen und Strukturen im Fachgebiet Gynäkologie und Geburtshilfe im Jahr 2011 - allgemeine Aspekte und geburtshilfliche Versorgung. II. Artikel der Finanzierungskommission der DGGG e.V. - Teil I. Geburtshilfe Frauenheilkd 2011;71:497-510.

12 Beckmann MW, Bader W, Bechtold I, Becker S, Bornhaupt J, Dimpfl T, Friese K, Frobenius W, Gembruch U, Grüssner S, Heer IM, Kayser D, Kreienberg R, Petri E, Rimbach S, Scharl A, Schmidt S, Schwenzer T, Solomayer E, Steiner E, Vetter K, Wallwiener D, Lux MP: Finanzierung und finanzielle Probleme von Leistungen und Strukturen im Fachgebiet Gynäkologie und Geburtshilfe im Jahr 2011 - DRG-System und stationäre Versorgung inklusive Urogynäkologie und benigner wie auch maligner gynäkologischer Operationen. II. Artikel der Finanzierungskommission der DGGG e.V. - Teil II. Geburtshilfe Frauenheilkd 2011;71:367-380.

13 Lux MP, Fasching PA, Löhberg CR, Jud SM, Schrauder MG, Bani MR, Thiel FC, Hack CC,
Hildebrandt T, Beckmann MW: Health services research and health economy - quality care training in gynaecology, with focus on gynaecological oncology. Geburtshilfe Frauenheilkd 2011;71:10461055 .

14 Wagner S, Bani MR, Fasching PA, Schrauder MG, Löhberg CR, Beckmann MW, Lux MP: Ist ein Brustzentrum finanzierbar? - Berechnung einzelner Leistungen am Beispiel des Universitäts-Brustzentrums Franken (UBF). Geburtshilfe Frauenheilkd 2008;68:1178-1183.

15 Bayerisches Staatsministerium für Umwelt und Gesundheit. Krankenhausplan des Freistaates Bayern 2012. Stand: 1. Januar 2012.

16 Scharl A: Kürzungen gefährden die Versorgung von Brustkrebspatientinnen. Forum 2012;6:450.

17 Hoffmann J, Wallwiener D: Breast cancer surgery and financial reimbursement in Germany. Breast Care 2012;7:348-388.

18 Jacobs VR, Rasche L, Harbeck N, Warm Mathias, Mallmann P: Underfinancing of $90.3 \%$ for implant costs of prostheses and expanders in DRG revenues for uni- and bilateral mastectomy with immediate breast reconstruction. Onkologie 2010; 33:584-588.

19 Singer S, Das-Munshi J, Brähler E: Prevalence of mental health conditions in cancer patients in acute care - a meta-analysis. Ann Oncol 2009;21:925930.

20 Mehnert A, Koch U: Psychological comorbidity and health-related quality of life and its association with awareness, utilization, and need for psychosocial support in a cancer register-based sample of long-term breast cancer survivors. J Psychosom Res 2008;64:383-391.

21 Berger AM, Abernethy AP, Atkinson A, Breitbart WS, Cella D, Cimprich B, Eisenberger MA, Escalante CP, Jacobsen PB, Kaldor P, Ligibel JA, Murphy BA, O'Connor T, Pirl WF, Rodler E, Rugo HS, Thomas J, Wagner LI: Cancer-related fatigue. J Natl Compr Canc Netw 2010;8: 904-931.
Lux/Hildebrandt/Beyer-Finkler/ Bani/Loehberg/Jud/Rauh/Schrauder/ Fasching/Beckmann 
22 Waadt S, Duran G, Berg P, Herschbach P: Progredienzangst. Manual zur Behandlung von $\mathrm{Zu}-$ kunftsängsten bei chronisch Kranken. Stuttgart, Schattauer, 2011.

23 Bundesministerium des Bundes. Nationaler Krebsplan. www.bmg.bund.de/praevention/nationaler-krebsplan/ der-nationale-krebsplan-stellt-sich-vor.htm2. February 2010.

24 Deutsche Krebsgesellschaft, Deutsche Gesellschaft für Senologie: Kennzahlauswertung 2012. Jahresbericht der zertifizierten Brustkrebszentren. Berlin, Deutsche Krebsgesellschaft, 2012. www.onkozert.de downloads/bz_allgemein_benchmarking\%202012A11\%28120628\%29.pdf.

25 Heckl U, Singer S, Wickert M, Weis J: Aktuelle Versorgungsstrukturen in der Psychoonkologie. Onkol Welt 2012;3:53-60.

26 Beckmann MW, Bani MR, Loehberg CR, Hildebrandt T, Schrauder MG, Wagner S, Fasching PA, Lux MP: Are certified breast centers cost-effective? Breast Care 2009:4:245-250.

27 Deutsche Krebsgesellschaft: Mitteilung an die Leiter der zertifizierten Darmkrebs- und Brustkrebszentren. Berlin, Deutsche Krebsgesellschaft, 2012.
28 Kowalski C, Wesselmann S, Ansmann L, Kreienberg R, Pfaff H: Key informants' perspectives on accredited breast centres: results of a survey. Geburtshilfe Frauenheilkd 2012;72:235-242.

29 Lux MP, Hildebrandt T, Bani MR, Schrauder MG, Löhberg CR, Fasching PA, Thiel FC, Mehlhorn G, Goecke TW, Kraml F, Wagner S, Beckmann MW: Gesundheitsökonomische Aspekte und finanzielle Probleme in den zertifizierten Strukturen des Fachgebietes. Gynäkologe 2011;44:816-826.

30 Beckmann MW, Brucker C, Hanf V, Bani MR, Petsch S, Schick S, Fasching PA, Hartmann A, Lux MP, Haeberle L: Quality assured health care in certified breast centers and improvement of prognosis of breast cancer patients. Onkologie 2011:34;362-367.

31 Heil J, Gondos A, Rauch G, Marmé F, Rom J, Golatta M, Junkermann H, Sinn P, Aulmann S, Debus J, Hof H, Schütz F, Brenner H, Sohn C, Schneeweiss A. Outcome analysis of patients with primary breast cancer initially treated at a certified academic breast unit. Breast 2012;21:303-308.

32 Kowalski C, Wesselmann S, Kreienberg R, Schulte H, Pfaff H: The patients' view on accredited breast cancer centers: strengths and potential for improvement. Geburtshilfe Frauenheilkd 2012; 72:137-143.
33 Kowalski C, Ansmann L, Wesselmann S, Pfaff H: Zertifizierte Brustkrebszentren aus Sicht von $\mathrm{Pa}$ tientinnen und Zentrumsleitungen. Forum 2012; 6:405-409.

34 Lux MP, Fasching PA, Bani MR, Schrauder M, Loehberg CR, Oppelt P, Hildebrandt T, Grün AH, Beckmann MW, Goecke T: Marketing von Brustund Perinatalzentren - Sind die Patientinnen mit dem Produkt 'zertifiziertes Zentrum' vertraut? Geburtshilfe Frauenheilkd 2009;69:1-7.

35 Lux MP, Fasching PA, Schrauder M, Löhberg C, Thiel F, Bani MR, Hildebrandt T, Grün AH, Beckmann MW, Goecke T: The age of centers: the influence of establishing specialized centers on patients' choice of hospital. Arch Gynecol Obstet 2011;283:559-568.

36 Thiel FC, Scharl A, Hildebrandt T, Kotziabassis E, Schrauder MG, Bani MR, Müller A, Hauzenberger T, Löhberg CR, Jud SM, Fasching PA, Hardtmann A, Schulz-Wendtland R, Strnad V, Beckmann MW, Lux MP: Financing of certified centers: a willingness-to-pay analysis. Arch Gynecol Obstet 2012; Epub ahead of print. 